DOI: $10.2478 / \mathrm{v} 10025-010-0016-7$

JOURNAL OF WATER

AND LAND DEVELOPMENT

J. Water Land Dev. No. 13a, 2009: 5-17

\title{
Characteristics of the forest floor water retention in the Carpathian experimental catchment basin of the Trzebuńka brook
}

\author{
Anna HOMA, Bolestaw OSUCH
}

Cracow University of Technology, Institute of Water Engineering and Water Management, ul. Warszawska 24, 31-155 Kraków, Poland; e-mail: anna.homa@iigw.pl

\begin{abstract}
The paper presents a description of retention reservoir and the process of rainfall water storage in forest floor as a function of time. It required investigation of reservoir filling in different conditions of active experiment. Laboratory conditions were the simplest to perform and allowed determination of retention in relation to water content in forest floor before sprinkling, i.e. to the initial retention. Maximum forest floor retention capability was also evaluated.

As an effect, formulas for maximum and current capacity evaluation are presented and the process of water retention in any kind of forest floor is described. Basic forest floor feature i.e. dry forest litter mass per area unit $\left(\mathrm{g} \cdot \mathrm{cm}^{-2}\right)$ is needed to determine its retention capabilities.
\end{abstract}

Key words: bound water, free water, forest floor, maximum retention, retention

\section{INTRODUCTION}

The paper addresses the problem of interest of both foresters and hydrologists - retention of precipitation in forest floor. The problem involves both the water needed to cover forest biological demands and the role of forests in hydrologic transformation of rainfall to outflow. Both aspects pertain to water balance in forests and in catchments. The study was aimed at estimating the possibility of rainfall retention in forest litter through theoretical considerations, laboratory experiments and field observations and at describing the process in a selected Carpathian catchment.

The main hypothesis was that water retention in forest litter (dealt with as a retention reservoir) may be described based on its physical features. It is also possible to describe the retention of part of atmospheric precipitation in litter based on experimental studies considering variable meteorological conditions and water inputs. 
The paper presents the description of retention reservoir and rainfall retention in forest floor in time. This required the study of reservoir fulfilment under variable conditions of active experiment which could best be performed in the lab. Laboratory experiments allowed for estimating the relationship between water content in forest litter before sprinkling - the so-called initial retention whose amount was established from meteorological parameters and field studies (HOMA, 2002). Maximum retention capacity of forest litter was also established. The characteristic of the retention reservoir of forest floor, assessment of its capacity and description of the process of fulfilment and emptying are given. The model of reservoir's structure is presented with the distinction of two sub-reservoirs: free water and bound water pool. Calculations of the total reservoir's volume and the volume of its components are presented with the use of its physical features which are relatively easy to measure. The paper is part of HOMA's (2003) doctor's thesis.

\section{THE MODEL OF RETENTION RESERVOIR OF FOREST FLOOR}

The description of the retention reservoir of forest floor was based on the following assumptions:

- characteristic of the retention reservoir of forest floor should have a form of mathematical formula whose independent variable (variables) would consist of selected physical features of the reservoir,

- physical features of forest litter should be estimated in objective terms, possibly through relatively simple measurement,

- considered changes of water retention in forest litter will involve only the input of sprinkling water and its losses through free infiltration of its excess into the substratum and evaporation to the atmosphere.

\section{DESCRIPTION OF THE STRUCTURE OF FOREST FLOOR RETENTION RESERVOIR}

Irrespective of the study site (MOLCHANOV, 1960; PLICHTA and GRELEWICZ, 1986; SULIŃSKI, 1993) the graph of water retention in forest litter during its sprinkling always shows rapid increment of water collecting above the initial level. The curve of sample fulfilment with water collapses later on even if sprinkling proceeds at the same rate. An example of water retention at interrupted sprinkling but constant intensity is shown in Fig. 1.

Water retention in forest litter presented schematically in Fig. 2 may be divided into two separate components:

a) retention of free water,

b) retention of bound water (Fig. 3) 


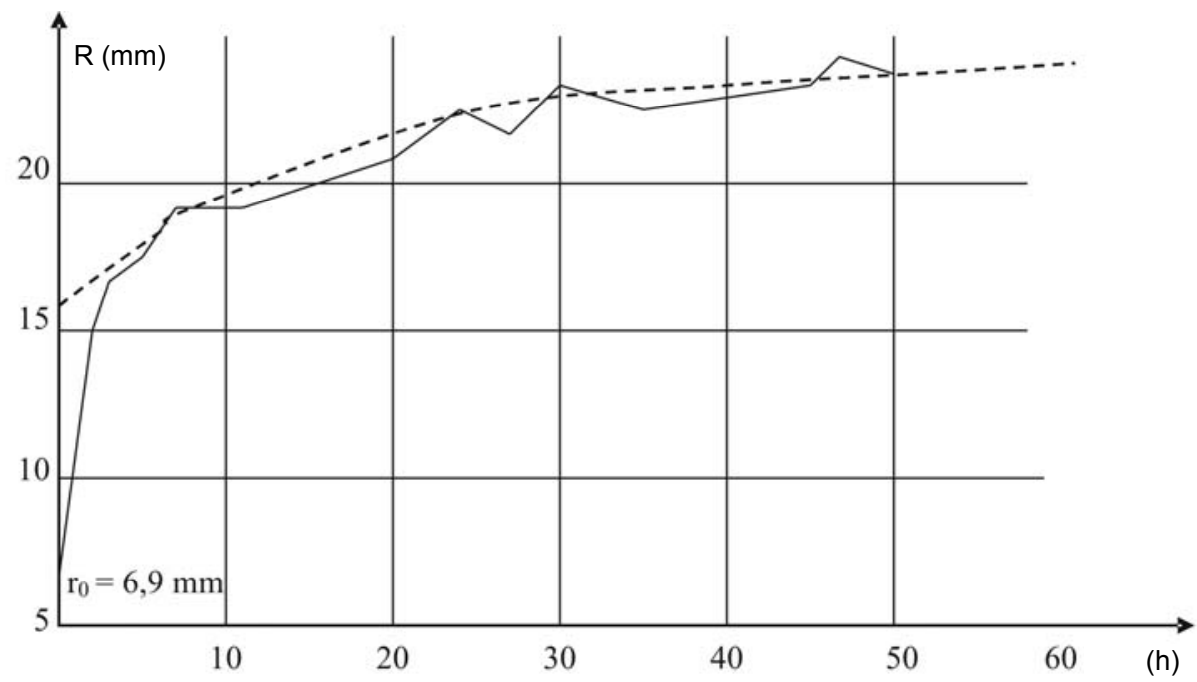

Fig. 1 . The course of water retention by forest litter sample (sample $2 / 95$, density $0.21 \mathrm{~g} \cdot \mathrm{cm}^{-3}$ )

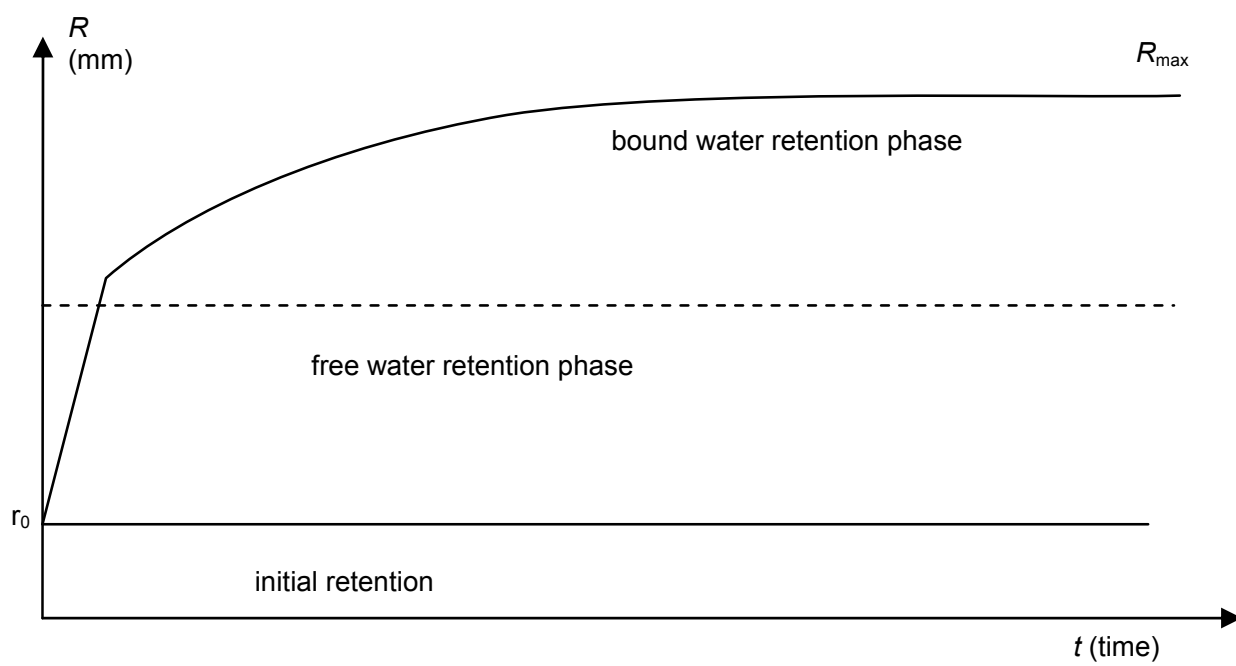

Fig. 2. Water retention in forest floor divided into the main processes

So, the total water retention in forest litter in time $t_{i}$ is the sum of water collected before precipitation $r_{o}$, bound water $R_{z i}$ and free water retention $R_{w i}$

Laboratory and field studies were necessary to assess the retention capacity of forest floor under conditions determining water retention in and outflow from forest litter.

$$
R_{t i}=r_{o}+R_{z i}+R_{w i}
$$




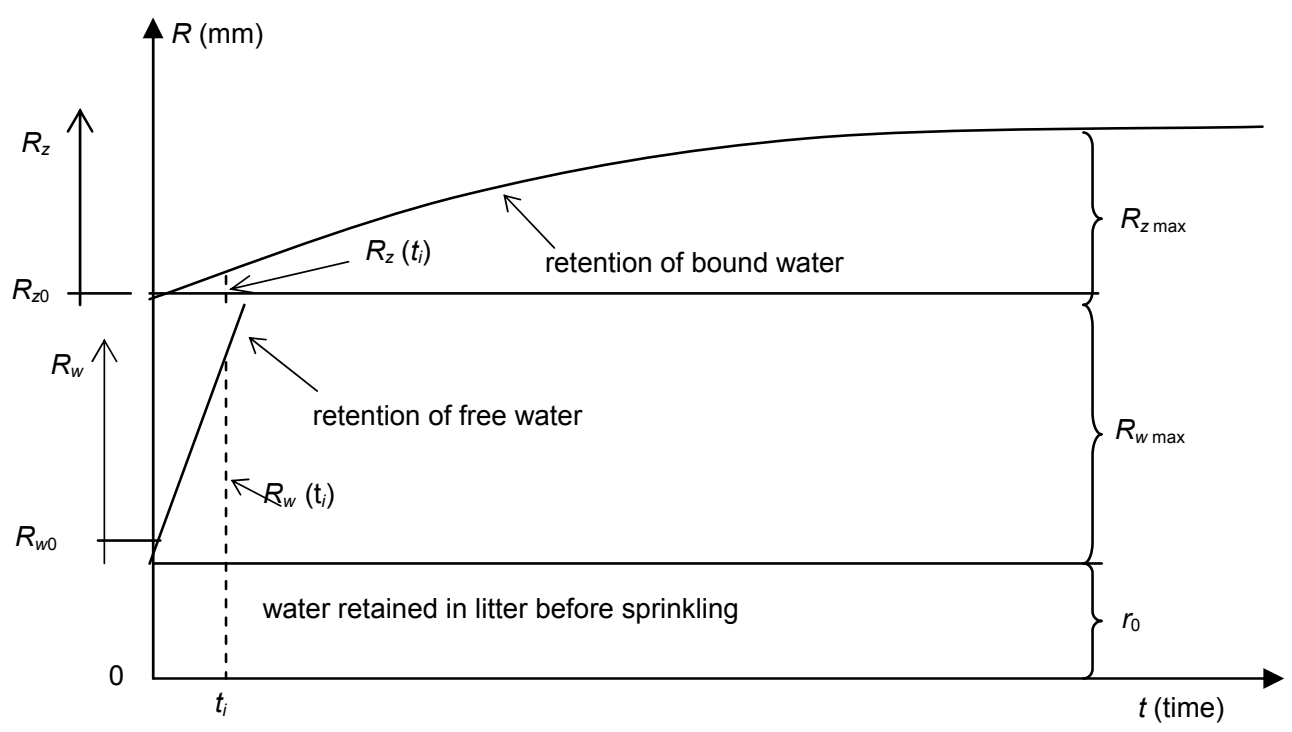

Fig. 3. Division of water retention in forest floor into free and bound water retention

\section{LABORATORY STUDIES ON THE WATER RETENTION CAPACITY OF FOREST LITTER}

First stage of laboratory studies was aimed at estimating the range and course of water retention in forest litter. Possibly undisturbed samples were cut from various places in the forest with a steel cylinder of a diameter of $24.8 \mathrm{~cm}\left(483 \mathrm{~cm}^{2}\right.$ of an area). Litter was cut at its base with a sharp metal plate replaced later by a dense metal net. The sample was transferred to the lab where it was weighed, measured and sprinkled. In the first stage the samples were sprinkled for 2.5 hours at a mean rate of $10 \mathrm{~mm} \cdot \mathrm{h}^{-1}$. After stabilisation of water outflow the samples were weighed again assuming they were maximally soaked with water. Then, the samples were dried at $105^{\circ} \mathrm{C}$ to constant weight. Finally, bulk density (G), initial retention and the change of retention in time were determined. In total 19 samples were analysed. In later, more detailed studies it appeared that the samples were able to take in an additional portion of water since the process of soaking was prolonged and mass increments of sprinkled samples asymptotically approached maximum value.

Studies from the year 1993 indicated that the curves of water fulfilment tended to increase further on. Therefore, the theoretical maximum value was calculated for each curve which in every case was higher than the measured. Results of these preliminary studies were described in HOMA and OSUCH (1994).

Based on these observations the procedure of further studies was set up in details so as to sprinkle with pre-defined intensity and to consider the rate of sample mass increments which were measured long enough. Laboratory measurements al- 
lowed for estimating maximum retention $\left(R_{\max }\right)$ of forest litter in relation to its dry weight per unit area $(\delta)$ and initial retention $\left(r_{0}\right)$ and for assessing the process of water retention in forest litter.

\section{ESTIMATION OF THE MAXIMUM RETENTION CAPACITY OF THE FOREST FLOOR}

Total retention capacity of the forest floor $R_{\max }(\mathrm{mm})$ is achieved when its both components i.e. free water pool $R_{w}(\mathrm{~mm})$ and bound water pool $R_{z}(\mathrm{~mm})$ are completely filled above the initial water content of analysed litter in the beginning of its fulfilment. Therefore:

$$
R_{\max }=r_{o}+\left(R_{w \text { max }}+R_{z \text { max }}-r_{o}\right)
$$

which can be seen in Fig. 3 and is equivalent to:

$$
R_{\max }=R_{w \max }+R_{z \max }
$$

Finally, maximum capacity of forest litter is the sum of maximum capacities of particular pools. This can be achieved by soaking the sample or better by its sprinkling. Fulfilment of forest litter lasts for a definite time period until both pools $\left(R_{w}\right.$ and $\left.R_{z}\right)$ are not able to retain extra amounts of water which manifests itself by a lack of litter mass increments despite its further sprinkling. Water retention in forest litter can best be studied under laboratory conditions.

The intensity of sprinkling is not important for estimating exclusively the maximum water retention of forest litter. It is, however, important to estimate the threshold water mass the sample can retain when sprinkled according to adopted experimental procedure. Together with the measurement of maximum retention of analysed sample expressed by the height of retained water layer $R_{\max }(\mathrm{mm})$, dry weight of litter per unit area $\delta\left(\mathrm{g} \cdot \mathrm{cm}^{-2}\right)$ was determined. Several dozen samples of forest litter were analysed in that way and results from 27 tests proceeding without interruption under comparable conditions and subjected to the same main factors were finally accepted.

Water retention by forest litter depends on the litter structure (spatial set up of organic particles i.e. the size of macro- and microporous space). For this reason, water layer retained by analysed sample $R_{\max }(\mathrm{mm})$ was related to dry weight of the sample per unit area $\delta\left(\mathrm{g} \cdot \mathrm{cm}^{-2}\right)$. The relationship has a form:

$$
R_{\max }=16.451 \delta+9.0861(\mathrm{~mm})
$$

Multiple correlation coefficient $R=0.94$. 
Results of measurements of the maximum water retention in samples of forest litter and their dry weight per unit area are given in Table 1.

Tabela 1. Results of measurements of the maximum water retention in samples of forest litter and their dry weight per unit area $\left(\delta-\mathrm{g} \cdot \mathrm{cm}^{-2}\right)$

\begin{tabular}{|c|c|c|c|}
\hline No. & $\begin{array}{l}R_{\max } \\
\mathrm{mm}\end{array}$ & $\begin{array}{c}\delta \\
\mathrm{g} \cdot \mathrm{cm}^{-2} \\
\end{array}$ & $\begin{array}{c}r_{o} \\
\mathrm{~mm}\end{array}$ \\
\hline 1 & 14.6 & 0.44 & 6.1 \\
\hline 2 & 16.3 & 0.52 & 6.6 \\
\hline 3 & 19.9 & 0.73 & 6.2 \\
\hline 4 & 20.0 & 0.61 & 3.7 \\
\hline 5 & 16.5 & 0.39 & 7.3 \\
\hline 6 & 15.9 & 0.46 & 4.1 \\
\hline 7 & 16.4 & 0.49 & 6.0 \\
\hline 8 & 18.7 & 0.61 & 8.6 \\
\hline 9 & 21.5 & 0.78 & 11.1 \\
\hline 10 & 18.1 & 0.61 & 6.7 \\
\hline 11 & 20.2 & 0.62 & 12.0 \\
\hline 12 & 24.0 & 0.82 & 10.7 \\
\hline 13 & 23.5 & 0.82 & 14.4 \\
\hline 14 & 13.4 & 0.27 & 5.9 \\
\hline 15 & 13.6 & 0.22 & 4.8 \\
\hline 16 & 15.8 & 0.40 & 5.0 \\
\hline 17 & 16.1 & 0.43 & 5.4 \\
\hline 18 & 13.6 & 0.20 & 2.9 \\
\hline 19 & 20.3 & 0.65 & 10.9 \\
\hline 20 & 15.5 & 0.39 & 9.0 \\
\hline 21 & 14.0 & 0.32 & 6.1 \\
\hline 22 & 13.6 & 0.29 & 6.1 \\
\hline 23 & 19.0 & 0.57 & 9.0 \\
\hline 24 & 14.3 & 0.32 & 4.7 \\
\hline 25 & 17.2 & 0.50 & 5.7 \\
\hline 26 & 12.4 & 0.19 & 3.2 \\
\hline 27 & 16.6 & 0.46 & 9.7 \\
\hline
\end{tabular}

Initial retention $r_{o}(\mathrm{~mm})$ should often be considered in estimating maximum retention $R_{\max }(\mathrm{mm})$. Based on obtained experimental results the relationships between maximum and initial retention for several selected $r_{o}$ values during sprinkling with the same intensity are presented in Figs 4 and 5. As seen in the graphs, the lines initially depart form each other depending on the initial retention but later approach to the same upper value which is the maximum retention $R_{\max }(\mathrm{mm})$. 


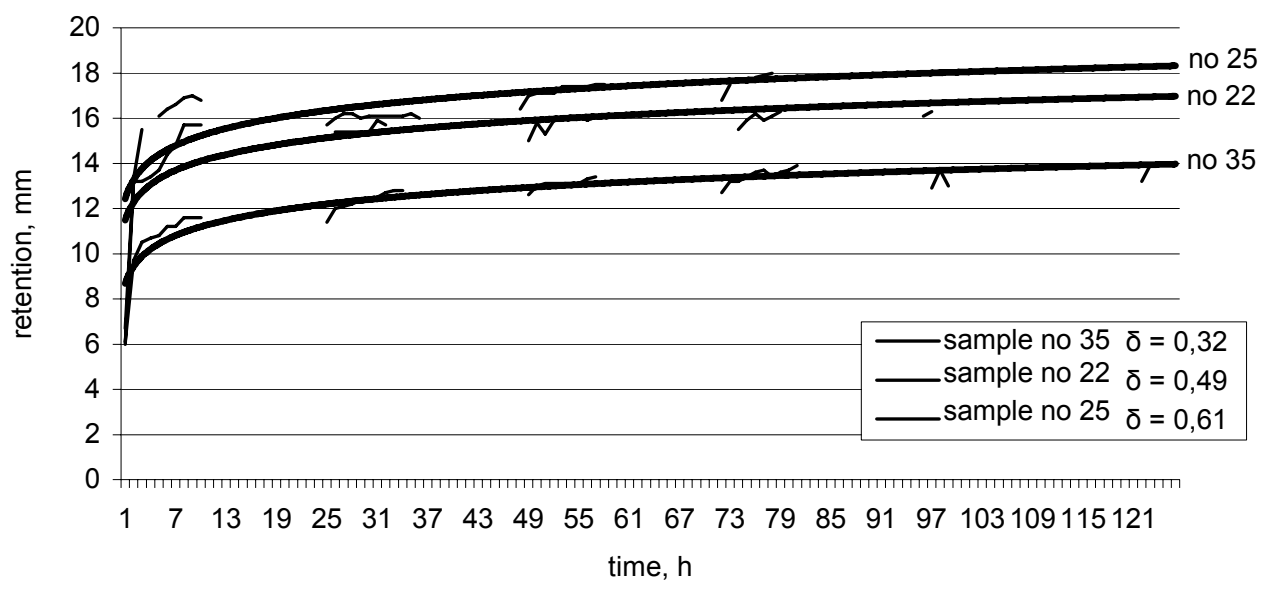

Fig. 4. Maximum retention $R_{\max }(\mathrm{mm})$ curves for various dry masses per unit area $\delta\left(\mathrm{g} \cdot \mathrm{cm}^{-2}\right)$ of forest litter at the same value of $r_{0}(\mathrm{~mm})$

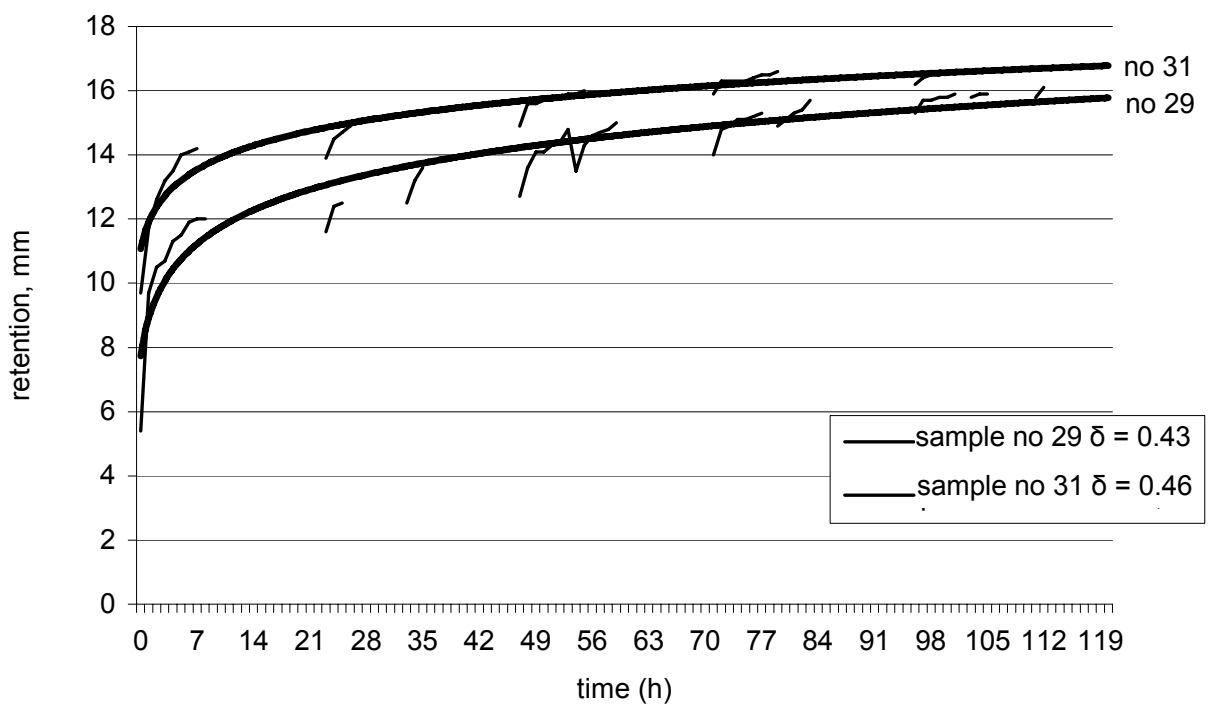

Fig. 5. Maximum retention $R_{\max }(\mathrm{mm})$ curves for various initial retentions $r_{\mathrm{o}}(\mathrm{mm})$

The relationship between maximum retention, dry weight of forest litter per unit area (Fig. 6) and initial retention can be described by regression:

$$
R_{\max }=21.30 \delta^{0.38} r_{o}^{0.036}(\mathrm{~mm})
$$

The coefficient of multiple regression is $R=0.94$. 


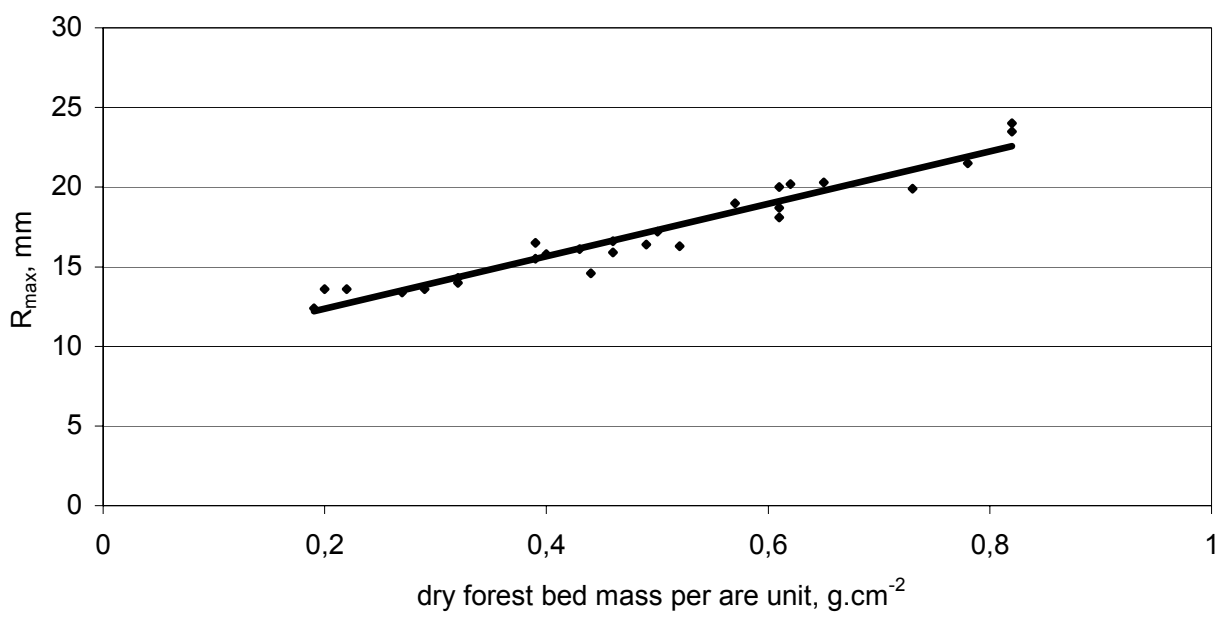

Fig. 6. The relationship between maximum retention $\left(R_{\max }-\mathrm{mm}\right)$ and dry mass per unit area of forest litter $\left(\delta-\mathrm{g} \cdot \mathrm{cm}^{-2}\right)$

\section{WATER RETENTION IN FOREST LITTER}

As already mentioned, water retention in forest litter is rapid in the first minutes and hours, later it slows down and further increments of retained water asymptotically approach the upper limit. Such a course was also found by other authors (PliChTA and GRELEWICZ, 1986; SULIŃSKI, 1993).

Describing the whole course by a single formula would be imprecise. Considering physical conditions of water retention in sprinkled litter one may conclude that initial retention indicates easy permeation of water in the surface layer of forest litter combined with the fulfilment of its internal macropore spaces. This is the retention of free water $R_{w}$ which is subjected to gravitation force. The fulfilment of micropores proceeds slower since it is associated with wetting the litter particles and filling tiny capillary spaces. This type of retention we will name the bound water retention $R_{z}$. Bound water will leave forest litter only by evaporation.

\section{FREE WATER RETENTION}

Fulfilment of free water pool takes place in the first stage of water retention in forest litter since the process is rapid and at the time more important than the collection of bound water. After filling all cavities and macropores (achieving the maximum value) the process rapidly stops. The excess of water flows out or is used to wet forest litter. Proposed general scheme of the process (Fig. 3) suggests that it may be described by linear regression of maximum fulfilment of free water pool on 
initial retention. The slope of the regression line, as found in laboratory experiments, depends on the intensity of sprinkling the forest litter. The lower the intensity the smaller is the regression slope. Free water retention during sprinkling of forest litter changes from $r_{o}$ at start to $R_{w(t i)}=R_{w \text { max. }}$ This may be described as:

$$
R_{w(i i)}=\left\{\begin{array}{c}
r_{o}+b t_{w i} \\
R_{w \max }
\end{array}\right\} \text { gdy } \begin{gathered}
0<t_{w i}<t_{w \max } \\
t_{w i} \geq t_{w \max }
\end{gathered}
$$

where:

$R_{w(t)} \quad$ - free water retention in the $i$-th time step $t_{w i}$ of sprinkling,

$R_{w \max }$ - time since the beginning of sprinkling till the moment when free water retention reservoir is filled i.e. when $R_{w}=R_{w \max }$,

b $\quad-$ constant.

Maximum free water retention $R_{w \max }$ falls between initial retention $r_{0}$ and total maximum retention $R_{\max }$. Therefore, $R_{w} \max$ should be related to $r_{0}$ and $R_{\max }$. One may expect that the intensity of sprinkling $J\left(\mathrm{~mm} \cdot \mathrm{min}^{-1}\right)$ might to some degree affect maximum free water status.

Combination of all these elements with $R_{w}$ max as a dependent variable should give expected result. Based on data from laboratory tests the relationship assumed a form of highly significant regression (Tab. 2):

$$
R_{w \max }=0.028 r_{0}^{-0.367} R_{\max }^{2.12} J^{0.066}(\mathrm{~mm})
$$

Table 2. Input data for estimating the regression of free water retention in forest litter $\left(R_{w \max }\right)$ on

\begin{tabular}{|c|c|c|c|c|c|c|}
\hline No & $\begin{array}{c}R_{w \max } \\
\mathrm{mm}\end{array}$ & $\begin{array}{c}r_{0} \\
\mathrm{~mm}\end{array}$ & $\begin{array}{c}R_{\max } \\
\mathrm{mm}\end{array}$ & $\begin{array}{c}J \\
\mathrm{~mm} \cdot \min ^{-1}\end{array}$ & \multicolumn{2}{|c|}{ Output } \\
\hline 1 & 6.2 & 5.0 & 13.8 & 1.00 & \multicolumn{2}{|c|}{ Statistics } \\
\hline 2 & 4.4 & 5.4 & 16.1 & 0.70 & multiple $R$ & 0.909343 \\
\hline 3 & 4.2 & 3.0 & 13.2 & 0.50 & $R^{2}$ & 0.826905 \\
\hline 4 & 5.3 & 10.9 & 20.3 & 0.40 & adjusted $R$ & 0.783632 \\
\hline 5 & 3.8 & 9.0 & 15.4 & 0.30 & standard error & 0.204476 \\
\hline 6 & 4.2 & 6.1 & 14.0 & 0.25 & $N$ & 12 \\
\hline 7 & 3.1 & 6.1 & 12.3 & 0.20 & & \\
\hline 8 & 5.5 & 9.0 & 19.1 & 0.15 & & \\
\hline 9 & 4.8 & 4.7 & 14.3 & 0.10 & & \\
\hline 10 & 4.0 & 5.7 & 14.5 & 0.05 & & \\
\hline 11 & 1.1 & 3.2 & 8.9 & 0.02 & & \\
\hline 12 & 3.4 & 9.7 & 16.6 & 0.01 & & \\
\hline
\end{tabular}
three independent variables

Explanations: $R$ - multiple regression coefficient, $R^{2}$ - coefficient of determination, adjusted $R$ - corrected regression coefficient, standard error - residual standard deviation 
Variability of free retained water, as seen in eq. 6 depends on time and on constant $b$ (slope). The value of $R_{w \max }$ estimates the point of intersection of extrapolated curve of total retention and the ordinate at the start of sprinkling. The increment of free water between $r_{0}$ and $R_{\max }$ is the difference between ordinates of extrapolated total retention curves from the start of sprinkling till the curve collapse and the level of maximum free water retention $R_{w \max }$. Ordinates estimated in that way enabled determination of the $b$ constant in experimental sprinkling of litter at a given intensity $J$ (Tab. 3).

Constant $b$ can be calculated from the regression:

$$
b=e^{0.965} J^{0.1848} \delta^{0.672}
$$

where:

$e$ - the base of natural logarithms,

$J$ - intensity of sprinkling $\left(\mathrm{mm} \cdot \mathrm{min}^{-1}\right)$,

$\delta-$ dry weight of forest litter per unit area $\left(\mathrm{g} \cdot \mathrm{cm}^{-2}\right)$.

Coefficient of multiple regression is high $-R=0,854$.

Tabela 3. Input data for estimating constant $b$ needed to calculate free water retention $\left(R_{w}\right)$

\begin{tabular}{r|c|c|c|lc}
\hline No & $b$ & $\begin{array}{c}J \\
\mathrm{~mm} \cdot \mathrm{min}^{-1}\end{array}$ & $\begin{array}{c}\delta \\
\mathrm{g} \cdot \mathrm{cm}^{-3}\end{array}$ & \multicolumn{2}{c}{ Output } \\
\hline 1 & 1.55 & 1.00 & 0.40 & & Statistics \\
2 & 1.20 & 0.70 & 0.43 & multiple $R$ & 0.853991 \\
3 & 0.975 & 0.50 & 0.20 & $R^{2}$ & 0.7293 \\
4 & 1.30 & 0.40 & 0.65 & adjusted $R$ & 0.669145 \\
5 & 0.975 & 0.30 & 0.39 & standard error & 0.257686 \\
6 & 1.05 & 0.25 & 0.32 & $N$ & 12 \\
7 & 0.77 & 0.20 & 0.29 & & \\
8 & 1.32 & 0.15 & 0.57 & & \\
9 & 1.20 & 0.10 & 0.32 & & \\
10 & 0.90 & 0.05 & 0.50 & & \\
11 & 0.27 & 0.02 & 0.19 & & \\
12 & 0.85 & 0.01 & 0.46 & & \\
\hline
\end{tabular}

Explanations as in Table 2.

\section{BOUND WATER RETENTION}

Bound water retention appears at the same time as free water retention i.e. at the start of sprinkling. At constant sprinkling intensity $J\left(\mathrm{~mm} \cdot \mathrm{min}^{-1}\right)$ the increment of retention gradually decreases approaching asymptotically zero at the moment of maximum fulfilment of forest litter retention reservoir. 
Maximum capacity of bound water pool $R_{z \max }$ results from the maximum retention of the whole interception pool of litter $R_{\max }$ diminished by the initial retention $r_{0}$ and by the maximum capacity of free water pool $R_{w \max }$ :

$$
R_{z \max }=R_{\max }-r_{0}-R_{w \max }(\mathrm{mm})
$$

The process of bound water retention from zero at the start of sprinkling till its maximum value can be described as a function of the intensity of sprinkling $J$ and retention properties of forest litter:

$$
R_{z(t)}=R_{z \max }\left(1-e^{-a t}\right)(\mathrm{mm})
$$

where:

a - constant expressing retention properties of forest litter,

$R_{z(t)} \quad$ - bound water retention at time $t$,

$R_{z \max } \quad$ - maximum bound water retention.

Dimensionless constant $a$ was estimated using significant regression (Tab. 4) for many variables characterising the litter in the catchment basin of the Trzebuńka:

$$
a=0.311 R_{z \max }^{-0.518} J^{0.078}
$$

Table 4. Input data for estimating constant $a$ needed to calculate maximum bound water retention $\left(R_{z \max }\right)$

\begin{tabular}{r|c|c|c|lc}
\hline No & $a$ & $\begin{array}{c}D \\
\mathrm{~mm}\end{array}$ & $\begin{array}{c}J \\
\mathrm{~mm} \cdot \mathrm{min}^{-1}\end{array}$ & \multicolumn{2}{c}{ Output } \\
\hline 1 & 0.04 & 30 & 0.01 & & Statistics \\
2 & 0.05 & 26 & 0.02 & multiple $R$ & 0.853991 \\
3 & 0.03 & 54 & 0.05 & $R^{2}$ & 0.7293 \\
4 & 0.03 & 44 & 0.10 & adjusted $R$ & 0.669145 \\
5 & 0.04 & 43 & 0.15 & standard error & 0.257686 \\
6 & 0.04 & 25 & 0.20 & $N$ & 12 \\
7 & 0.04 & 32 & 0.25 & & \\
8 & 0.06 & 19 & 0.30 & & \\
9 & 0.06 & 38 & 0.40 & & \\
10 & 0.03 & 57 & 0.50 & & \\
11 & 0.05 & 52 & 0.70 & & \\
12 & 0.07 & 20 & 1.00 & & \\
\hline
\end{tabular}

Explanations as in Table 2. 
Finally, we obtain total retention of forest litter at time $t$ since the start of sprinkling by summing up initial retention $r_{0}$, free water retention $R_{w(t)}$ and bound water retention $R_{z(t)}$ i.e.:

$$
R_{c(t)}=r_{0}+R_{w(t)}+R_{z(t)}(\mathrm{mm})
$$

Initial retention was estimated by the author in HOMA [2002].

\section{CONCLUSIONS}

Presented paper was aimed at analysing retention properties of forest litter one of retention pools in forest ecosystem - and at estimating the method of assessment of these properties. One of the basic aims of this study was to present the method of estimation of maximum and current retention capacity and to show the course of water retention in any forest litter of Carpathians catchment basins. Adoption of dry weight of forest litter per unit area $\left(\mathrm{g} \cdot \mathrm{cm}^{-2}\right)$ as a basic physical property of litter was the basis for estimating maximum and actual capacity of the retention reservoir of forest litter and for describing the process of this pool fulfilment.

Maximum retention capacity of forest litter is four to five times larger than the maximum interception capacity of tree stand whose floor is covered with litter. However, actual available capacity of forest litter is smaller since the litter practically retains the so-called initial retention which is 10 to $30 \%$ of the maximum. Moreover, the process of water retention and release is different in tree stand and in forest litter. Tree stand has usually full retention capacity at its disposal and after fulfilment with rainfall it relatively fast (several hours) reconstructs its retention capabilities. Filled pool of forest litter needs several rainless days (7-9) to return its retention status to that from before rainfalls.

\section{REFERENCES}

1. Homa A., 2002. Ustalenie retencji początkowej w ściółce leśnej na tle warunków meteorologicznych. Czas. Tech. 5-Ś.

2. HomA A., 2003. Retencja opadu w ściółce leśnej w karpackiej zlewni badawczej potoku Trzebuńki. Kraków, PKrak. PhD-Thesis

3. Homa A., Osuch B., 1994. Rozpoznawcze badania zdolności retencyjnej ściółki leśnej. Czas. Tech. 4-B.

4. Molchanov A.A., 1960. Gidrologičeskaa rol' lesa. Moskva, Izd. AN SSSR.

5. Plichta W., Grelewicz A., 1986. Charakterystyka wodnych właściwości absorpcyjnych materiału organicznego różnych typów próchnic leśnych. Rocz. Gleb., 37, 2-3.

6. SULIŃSKI J., 1993. Modelowanie bilansu wodnego w wymianie między atmosfera, drzewostanem i gruntem przy użyciu kryteriów ekologicznych. Zesz. Nauk. AR Krak. Rozpr. Habil., 179: 133. 


\section{STRESZCZENIE}

\section{Charakterystyka ściółki leśnej jako zbiornika retencyjnego w zlewni badawczej potoku Trzebuńki (Karpaty)}

Słowa kluczowe: retencja, retencja maksymalna, ściótka leśna, woda wolna, woda zwilżajaca

Prezentowane $\mathrm{w}$ pracy miały za cel rozpoznanie właściwości retencyjnych ściółki leśnej oraz określenie sposobów oceny tych właściwości. U podstaw realizacji tej pracy przyjęto założenia dotyczące określenia poszukiwanych wartości, zależności od wybranych cech fizycznych ściółki leśnej, które stosunkowo łatwo można byłoby ustalić poprzez wykonanie prostych pomiarów. Jednym z podstawowych celów badań było podanie sposobu określenia zdolności maksymalnej, bieżącej oraz przebiegu procesu retencji wody przez dowolną ściółkę leśną.

Badania laboratoryjne obejmowały określenie:

- maksymalnej pojemności ściółki leśnej jako zbiornika retencyjnego oraz jej podzbiorników, tj. wody wolnej i wody zwilżającej, w zależności od wartości suchej masy ściółki leśnej przypadającej na jednostkę powierzchni terenu (1 $\left.\mathrm{cm}^{2}\right)$;

- sposobu napełniania zbiornika i opisu tego procesu poprzez podanie równań regresyjnych napełniania zbiornika wody wolnej i wody zwilżającej łącznie, decydujących o całkowitym zatrzymaniu wody w ściółce leśnej.

Procesy te uzależniono od retencji maksymalnej zbiorników składowych, od natężenia zraszania i od retencji początkowej.

Reviewers:

Prof. Józef Suliński

Dr. Jan Tyszka 